Meta

Journal des traducteurs

Translators' Journal

\title{
(Re)translation Revisited
}

\section{Isabelle Desmidt}

Volume 54, numéro 4, décembre 2009

URI : https://id.erudit.org/iderudit/038898ar

DOI : https://doi.org/10.7202/038898ar

Aller au sommaire du numéro

\section{Éditeur(s)}

Les Presses de l'Université de Montréal

\section{ISSN}

0026-0452 (imprimé)

1492-1421 (numérique)

Découvrir la revue

\section{Citer cet article}

Desmidt, I. (2009). (Re)translation Revisited. Meta, 54(4), 669-683. https://doi.org/10.7202/038898ar

\section{Résumé de l'article}

Le désir de se conformer aux nécessités nouvelles de la culture d'accueil motive les retraductions, qui manifestent ainsi la relativité des traductions dans l'histoire. Selon l'hypothèse dite, précisément, de retraduction, les retraductions tendent à être plus sourcières que les premières versions. Les premières traductions dévient davantage de l'original que les suivantes, plus récentes, parce qu'elles déterminent si un texte et son auteur vont être acceptés dans la culture cible. Plusieurs facteurs peuvent appuyer cette hypothèse de retraduction, qui serait même étendue à la réécriture (par exemple, les traducteurs critiquent les premières traductions, la langue cible s'est développée et les normes de la culture cible se sont assouplies), mais on peut néanmoins se demander si elle est vérifiée par des données empiriques. Le présent article fait état de résultats issus d'une étude, menée par l'auteure, en rapport avec l'hypothèse de retraduction. Cette étude porte sur 52 traductions en allemand et 18 traductions en hollandais du roman pour enfant bien connu de Selma Lagerlöf, Nils Holgerssons underbara resa genom Sverige (1906-1907 ; Le merveilleux voyage de Nils Holgersson en Suède), publiées de 1907-1908 à 1999. Bien que certaines versions récentes montrent un certain respect de l'original, une confrontation de différentes normes mène à une réfutation de l'hypothèse : pas d'allégeance à l'original, mais une suprématie des normes littéraires, pédagogiques et économiques. L’hypothèse, clairement, ne peut être généralisée. Si elle peut se révéler juste dans une certaine mesure, elle ne saurait en tout cas être formulée en termes absolus. Autant dans les formes périphériques de littérature, comme la littérature jeunesse, que dans la littérature classique, les (ré)écritures s'éloignant des formes prototypiques se révèlent être l'exception plutôt que la règle, et les normes de la culture cible continuent de se confronter à la fidélité au texte source original.
Ce document est protégé par la loi sur le droit d'auteur. L’utilisation des services d'Érudit (y compris la reproduction) est assujettie à sa politique d'utilisation que vous pouvez consulter en ligne.

https://apropos.erudit.org/fr/usagers/politique-dutilisation/ 


\title{
(Re)translation Revisited
}

\author{
ISABELLE DESMIDT \\ Ghent University - Sint-Franciscusinstitute Evergem, Ghent, Belgium \\ i.desmidt@telenet.be
}

\begin{abstract}
RÉSUMÉ
Le désir de se conformer aux nécessités nouvelles de la culture d'accueil motive les retraductions, qui manifestent ainsi la relativité des traductions dans l'histoire. Selon l'hypothèse dite, précisément, de retraduction, les retraductions tendent à être plus sourcières que les premières versions. Les premières traductions dévient davantage de l'original que les suivantes, plus récentes, parce qu'elles déterminent si un texte et son auteur vont être acceptés dans la culture cible. Plusieurs facteurs peuvent appuyer cette hypothèse de retraduction, qui serait même étendue à la réécriture (par exemple, les traducteurs critiquent les premières traductions, la langue cible s'est développée et les normes de la culture cible se sont assouplies), mais on peut néanmoins se demander si elle est vérifiée par des données empiriques. Le présent article fait état de résultats issus d'une étude, menée par l'auteure, en rapport avec l'hypothèse de retraduction. Cette étude porte sur 52 traductions en allemand et 18 traductions en hollandais du roman pour enfant bien connu de Selma Lagerlöf, Nils Holgerssons underbara resa genom Sverige (1906-1907; Le merveilleux voyage de Nils Holgersson en Suède), publiées de 1907-1908 à 1999. Bien que certaines versions récentes montrent un certain respect de l'original, une confrontation de différentes normes mène à une réfutation de l'hypothèse: pas d'allégeance à l'original, mais une suprématie des normes littéraires, pédagogiques et économiques. L'hypothèse, clairement, ne peut être généralisée. Si elle peut se révéler juste dans une certaine mesure, elle ne saurait en tout cas être formulée en termes absolus. Autant dans les formes périphériques de littérature, comme la littérature jeunesse, que dans la littérature classique, les (ré)écritures s'éloignant des formes prototypiques se révèlent être l'exception plutôt que la règle, et les normes de la culture cible continuent de se confronter à la fidélité au texte source original.
\end{abstract}

\begin{abstract}
Resulting from the wish to meet the (new, altered) requirements of the receiving culture, retranslations are exponents of the historical relativity of translation. According to the so-called retranslation hypothesis, retranslations tend to be more source culture oriented than first translations. First translations, the hypothesis runs, deviate from the original to a higher degree than subsequent, more recent translations, because first translations determine whether or not a text (and its author) is (are) going to be accepted in the target culture. One can come up with several factors that make the retranslation hypothesis, even broadened to re-rewriting hypothesis, plausible (e.g., translators take a critical stance to earlier translations, the target language has developed and target culture norms have become less rigid), but one can ask to what extent the hypothesis is supported by empirical evidence. In the following article some of the results of my study of 52 German and 18 Dutch versions of the children's classic book Nils Holgerssons underbara resa genom Sverige (Nils Holgersson's Wonderful Journey Through Sweden, Selma Lagerlöf, 1906-1907), published between 1907-1908 and 1999, are discussed with respect to the retranslation hypothesis. It is argued that, though some more recent versions showed consideration for the original, a clash of norms ultimately did not allow the hypothesis to hold good: not allegiance to the original, but literary, pedagogical and economical norms gained the upper hand.The hypothesis clearly does not have a general value. The hypothesis may be
\end{abstract}


valid to some extent, but only if it is not formulated in absolute terms. Within peripheral forms of literature, like children's literature, as well as within classical literature, less prototypical (re)rewriting has proven to be more than the exception and target norms continue to clash with fidelity to the original source text.

\section{MOTS-CLÉS/KEYWORDS}

retraduction, réécriture, normes, prototype, littérature pour enfants

retranslation, rewriting, norms, prototype, children's literature

\section{Historicism's Inevitability}

Translating can be seen as a problem-solving activity. It offers a solution to the communication breakdown that language barriers may cause. Sometimes, communication may be successful without translation too, especially when dealing with a transfer from a superior culture, i.e., from a geographical and/or political point of view, to a minor culture, or when dealing with multilingualism in the receiving culture. ${ }^{1}$ But mostly, language barriers are tenacious and some kind of translation is being called for.

Regarding translating as the solving of a social, communicative problem calls attention to the relativity of translation. As problem and solution interdepend, changes in social context will lead to changes both in translations and in the way translations are looked upon. Therefore, every translation as well as every definition of what is a (good) translation is relative; there will never be such a thing as 'the' perfect translation or 'the' translation theory.

The final shape of a translation is indeed determined by the numerous factors that are involved in the communication process: the message to be transferred (the text to be translated ${ }^{2}$ ), all the partners involved (e.g., author, translator, target text reader, as well as editor, publisher, distributor, illustrator and critic) and also the intended function of the translation. Moreover, translating is also governed by numerous norms. Norms arise when one particular way of solving a problem has proven to be effective and as a result of this success becomes standard procedure. Norms tell a community what procedures are usual and preferable, just like conventions, but in addition they are normative, telling the members of the community "how they ought to behave" (Hermans 1999: 81, original emphasis). All social life is constantly influenced by norms, which makes it impossible to dissociate translation from its broader historical context. Historicism clearly is inevitable.

\section{Retranslation and Retranslation Hypothesis}

Exponents of the historical relativity of translation are the so-called retranslations, i.e. new translations of earlier translated texts. Especially older, classical works have been frequently retranslated, but even more recent and/or less canonical texts - one can even take into consideration technical texts such as brochures or instructions - are often subject to retranslations. Retranslations result from the wish to meet the requirements of the receiving culture, requirements that are obviously not (no longer or not entirely) met by the existing translation(s). As cultures continuously change, every generation may take a different view on what is a good, i.e., functional, translation and may ask for the creation of a new translation. 
Despite the relativity of translation and the (relative) unpredictability of cultural evolution, translation scholars have asked and continue to ask whether or not retranslations have common (universal?) characteristics. In Translation Studies there is in fact the so-called retranslation hypothesis according to which retranslations tend to be more target culture oriented than first translations. First translations, the hypothesis runs, deviate from the original to a higher degree than subsequent, more recent retranslations, because first translations determine whether or not a text (and its author) is (are) going to be accepted in the target culture; the text is therefore adapted to the norms that govern the target audience. At a later stage, when it has become familiar with the text (and author), the target culture allows for and demands new translations - retranslations - that are no longer definitively target oriented, but source text oriented.

The retranslation hypothesis can be associated with the German romantic movement, in which 'Volk,' 'Sprache' and 'Kunst' were seen as organic entities and language and race as inseparable. The source text oriented approach was therefore seen as the only 'real' way of translating, as it was unnatural for the translator to translate as if the original author was part of the target culture. Goethe argued that translations develop from target culture oriented to source text oriented, eventually reaching the last and highest stage, "in which one tries to make the translation identical with the original" (Goethe 1811/1814: 244: "wo man die Übersetzung dem Original identisch machen möchte"; on the evolution of (re)translations, see also Goethe 1819: 243-246.). Schleiermacher (1813), who at this moment formulated his famous distinction between alienated translation (leading the reader towards the text) and integrated translation (leading the text towards the reader), was convinced that a target oriented approach could not lead to anything but an adaptation (paraphrase, imitation), which by definition was (is) unable to render the original work.

German romanticism has had a great influence on Translation Studies. Although often in a disguised form, as in Nida's (1964) formal equivalence and dynamic equivalence and Toury's adequacy and acceptability (1995), Schleiermacher's dichotomy is still very much part of the debate on so-called equivalence, i.e., the relation of similarity between source text and target text, one of the most long-lasting discussions in Translation Studies (see Koller 1995: 191-222, Chesterman 1997: 9, Halverson 1997: 207-233). The retranslation hypothesis is influential too, especially in view of the growing interest in the target culture ${ }^{3}$ and the influence of norms on the translation process (see Chesterman 1997 and Schäffner 1999). Translations are still seen as organic, as continuously evolving. ${ }^{4}$ In 1990, the journal Palimpsestes devoted an entire issue (issue 4) to "Retraduction" (retranslation) and referred to the retranslation hypothesis explicitly (for a definition of the hypothesis, see Bensimon 1990: iv-xiii).

One can ask, however, to what extent the hypothesis is supported by empirical evidence. Skjønsberg for instance argues that translations of children's literature in former days tended to be closer to the original text than more recent translations, thus arguing the exact opposite of the retranslation hypothesis (see Skjønsberg 1982: 42). It is in fact remarkable that no article in Palimpsestes concerns the translation of children's literature, which makes one wonder whether the retranslation hypothesis might only apply to a certain kind of corpus.

It would be interesting to further inquire into the retranslation hypothesis and determine its scope so as to know to what extent we are dealing with reality and to 
what extent we are dealing with myth or pure speculation. "Corpus study remains to be carried out in order to better define the concept of retranslation," Gambier (1994: 16) writes: "Un travail sur corpus reste à faire pour mieux cerner le concept de retraduction." In this regard it might be fruitful to go into some of the results of my study of 52 German and 18 Dutch versions of Nils Holgerssons underbara resa genom Sverige (Nils Holgersson's Wonderful Journey Through Sweden, Selma Lagerlöf, 1906-19075,6,7), the Swedish children's classic that tells the story of the fourteen-yearold Nils Holgersson, who, transformed into a gnome and accompanied by a domesticated goose, joins a flock of wild geese on their journey through Sweden. The study lays bare the genealogical relationships between the different versions (some versions were found to have served as source texts for other versions) as well as the way in which the original Swedish story has been treated (content analysis), and it deals with issues that may be of interest with respect to the retranslation hypothesis (Desmidt 2001).

\section{3. (Re)rewriting and Re-rewriting hypothesis}

To link up my study of Nils Holgersson with the retranslation hypothesis I need to broaden the perspective first and need to take into consideration not only interlingual (re)rewriting, i.e., (re)translation in the narrow sense of the word (from one language to another), but also other forms of (re)rewriting. ${ }^{8}$

In fact, the corpus consisted solely of versions that in comparison to the Swedish original could be designated as 'intramedial' (re)rewritings of the Swedish original, i.e., composed within the same medium (written text, book), and also as 'interlingual' (re)rewritings (written in German or Dutch as opposed to Swedish), for included in the corpus were the new editions (i.e., versions that were published by different publishing companies or versions that constituted a new item in a publisher's list) and the revised editions of Nils Holgersson in book form, published in Germany, Switzerland, Austria, the Netherlands and Belgium between 1906/1907 (publication of the Swedish original) and 1999. ${ }^{9}$ In relation to the immediate source text, however, most versions (namely 49, i.e., 70 percent of the corpus) were re-rewritten intralingually, i.e., within one and the same language. The publishing companies that reedited and/or reviewed Nils Holgersson had not used the Swedish original as the main source text, but an already existing German or Dutch version, which was re-edited and/or revised (mainly) intralingually. Six versions (i.e., 8.6 percent of the corpus) were even found to be re-rewritten intermedially, i.e., from one medium into another, namely from TV-serial into book. In other words, most versions in the corpus turned out to be indirect re-rewritings; they did not go back to the primary source text directly.

Even some of the interlingual re-rewritings in the corpus were found to be indirect. For her interlingual re-rewriting into German, for instance, Mathilde Mann started from the Danish rewriting by Ida Falbe-Hansen. Thus, not the Swedish original, but an existing (direct) interlingual rewriting had served as the immediate source text. Similarly, some Dutch versions were found to be interlingually re-rewritten from a German source text.

The corpus clearly displayed a wide diversity of versions, including both interlingual, intralingual and intermedial (re)rewritings, a diversity that most contributors 
to the above mentioned Palimpsestes issue on retranslation do not primarily start from. As can be derived from the examples given by the different contributors, "(re)traduction" is primarily seen as direct, i.e., going directly back to the original source text, and interlingual. ${ }^{10}$

My study, which has dealt with many more forms of (re)rewriting than merely the prototypical interlingual (re)rewriting, i.e., the prototypical (re)translation, may nevertheless be of interest to the retranslation hypothesis if one is willing to slacken the (ideal of) directness and interlingualism. In fact, as was argued above, such slackening is necessary to explore the scope of the retranslation hypothesis and is even found in Palimpsestes, particularly in the contributions by Antoine Berman and Liliane Rodriguez, where the complexity of (re)translation is stressed. Berman discusses the difficulty of distinguishing retranslation from translation, as some texts may be ambivalent. ${ }^{11}$ Rodriguez in turn points out that (re)rewriting may be intermedial (oral text versus written text, see Rodriguez 1990: 67: "On a parfois une traduction orale [...] d'un texte écrit, ou vice versa.") and she discusses the difficulty of distinguishing retranslation from adaptation: "Not enough changes or reformulations, and the 'retranslation' is only 'revision'; too many changes, reformulations, and the 'retranslation' becomes 'adaptation"” (see Rodriguez 1990: 65: "Pas assez de retouches ou de réécriture, et la 'retraduction' n'est que 'révision'; trop de retouches, de réécriture, et elle devient 'adaptation'”).

Rodriguez is certainly right in that a corpus of (re)rewritings may display a wide diversity in the way the source text is treated. Whereas the first edition in one volume of the German translation of Nils Holgersson by Klaiber, published in 1909, has 504 pages, the 'Klaiber version' edited by Reclam in 1951, for instance, has 95 pages, the Klaiber version that was published by Deutscher-Taschenbuch-Verlag in 1961 has 217 pages and the Klaiber version that is part of Lagerlöf's collected works as edited by Nymphenburger Verlagshandlung in 1980 has 367 pages. Unlike Rodriguez, however, I do not wish to look upon (re)translation/(re)rewriting and adaptation as opposed to each other in a binary way. I wish to argue that (re)rewriting, be it interlingual, intralingual or intermedial, can be seen as a prototype category, ranging on a cline between prototypical 'copying' (for interlingual (re)rewriting one could retain the word '(re)translation') to prototypical 'adapting.' One version can be closer to the pole of 'copy,' i.e., (re)rewriting with hardly any changes (for intralingual (re)rewriting exact copying is possible), while another version can be closer to the pole of 'adaptation,' revising. It is no use trying to categorically separate (re)rewriting from adaptation, as (re)rewriting - apart from exact intralingual re-editing - inevitably entails change; the difference is only one of degree. Moreover, it is the implication of change on which the retranslation hypothesis is based. Departing from the principle that with every new translation all kinds of revision are possible, the hypothesis states that revisions usually evolve in such a way that retranslations are increasingly faithful to the primary source text.

As not only interlingual retranslation, but all re-rewriting, i.e., also intralingual and intermedial re-rewriting, entails change, one wonders if and to what extent the retranslation hypothesis also holds for re-rewriting in general. Is the growing consideration for the original typical for all forms of re-rewriting, so that we actually are dealing with a re-rewriting hypothesis? For instance, when re-editing an existing translation, i.e., when intralingually re-rewriting an existing interlingual rewrit- 
ing, one may choose to go back to the primary source text and make the existing translation more truthful to it (to whatever extent one wishes to revise). Such a combination of indirect, intralingual revision with direct, interlingual revision does not correspond to the traditional view on (re)translation, even though direct and interlingual (re)rewriting is involved. It is, however, an argument in favor of a re-rewriting hypothesis, which is why I wish to explore this broader perspective and go into some of the results of my study of Nils Holgersson in German and Dutch (re)rewriting.

\section{Case Study - Nils Holgersson in German and Dutch (Re)rewriting}

As was said earlier, for my study of Nils Holgersson I thoroughly compared (the content of) 70 German and Dutch versions, covering a period of little more than 90 years (from 1906-1907 until 1999). Two of these versions were translations in the narrow sense of the word: the first direct and interlingual rewriting into German by Pauline Klaiber, published in three volumes in 1907-1908, and the first direct and interlingual rewriting into Dutch by Margaretha Meyboom, published in two volumes in 1911. All other 68 versions of the corpus were re-rewritings, which is a far more extensive corpus than the ones studied in the Palimpsestes issue on retranslation. This is what the study of Nils Holgersson revealed:

In keeping with the re-rewriting hypothesis, the first German and the first Dutch direct and interlingual rewritings were found to have taken into consideration the receiving culture, which had led to numerous changes. A quantitave analysis, as was part of my study, showed a deviation from the original by 16 and 31 percent respectively. This percentage expresses the number of the Swedish original's 97 chapters that were found to be 'changed.' A chapter was labeled as 'changed' if it was found to be either (1) completely deleted, (2) deleted and compensated: a new text part, e.g., a short summary, was added to compensate for the deletion, or (3) internally altered. The internal alterations could either concern shortenings (sentences, paragraphs were deleted, but not the chapter as a whole), substitutions (certain sentences, paragraphs were substituted by new sentences/paragraphs) or extensions (sometimes extra sentences/paragraphs were added). ${ }^{12}$ To clarify the method I used, it should also be noted that one can distinguish four 'dimensions' in the Swedish book: (1) Nils Holgersson was ordered by the Swedish government to be used as a class book in national geography and consequently includes many geographical facts, (2) it is a travel story, which also implies many geographical data, (3) it is an adventure story, full of action and suspense, and (4) it is a Bildungsroman, describing the evolution of a young good-for-nothing into a responsible young citizen. The internal alterations (shortenings, substitutions and extensions) were linked to these different dimensions, so as to investigate which dimension(s) was (were) mainly altered (e.g., extensions mostly concerned the adventure story as new figures and adventures were invented and added).

Klaiber's translation displayed predominantly internal, moral alterations (Nils is not as impudent as in the original, but more considerate, and the passages in which he is afraid of the dark are deleted), whereas Meyboom's translation was characterized by the deletion of entire chapters, particularly of chapters that included many geographical facts (14 of 97 chapters are deleted completely). In fact, the Swedish original was written by order of the Swedish authorities, who wanted a new textbook 
in national geographics, which is why one can find many geographical facts in the original. For the Dutch public, however, the book did not need to function as a textbook, and this obviously, led rewriters to drop some of the numerous geographical facts.

If one calculated the deviation from the Swedish original for every re-rewriting in the corpus - indirect versions were compared with the Swedish original indirectly, through their immediate source text, by verifying what changes they had or did not (no longer) have in common with the immediate source text - and subsequently set out the versions on a cline between 0 percent of change (i.e., the pole of prototypical copying) and 100 percent of change (i.e., the pole of prototypical adaptation), it was immediately clear that the re-writing hypothesis could not be corroborated. Starting from the re-rewriting hypothesis, one expected the most recent versions to be closest to the pole of prototypical copying (change 0 percent). But this was not the case. All eleven versions that were edited in the 1990s deviated more than 50 percent as well as for 19 of the 21 versions that were edited in the 1980s, while the version with the fewest changes went back to 1919. This version from 1919 was the edition in two volumes of the above-mentioned re-rewriting by Mathilde Mann, which was not rewritten from the Swedish, but from Danish. Such indirect re-rewriting can hardly be said to be evidence of an increasing consideration for the original. Furthermore, in Mann's re-rewriting still seven percent of the original's 97 chapters were found to be changed.

If one only looked at the direct interlingual re-rewritings in the corpus, i.e., the four German re-rewritings that went back to the Swedish original directly, the rerewriting hypothesis did not hold good either. With a deviation percentage of 15 , only the re-rewriting by André Foelckersam was more faithful to the Swedish original than the first German rewriting by Klaiber. Foelckersam's text, however, was published in 1949 and was the oldest of the direct re-rewritings. The other direct re-rewritings went back to 1985 (rewritten by Monika Trittibach-Andres), 1991 (rewritten by Angelika Kutsch) and 1994 (rewritten by Gisela Perlet) and turned out to have changed the Swedish original by 99, 87 and 62 percent respectively. ${ }^{13}$

Something could be said in favor of the re-rewriting hypothesis too. Some of the indirect versions of the corpus had used the Swedish original as an extra source text to 'correct' the source text from which they started. Klaiber's rewriting for instance, which was published for the first time in 1907-1908, was gradually rectified in the intralingual re-rewritings from 1909, 1928, 1942, 1948 and 1966.

In many cases, however, the correction needed to be qualified. The changes in Klaiber's original text were gradually reduced, from 16 to 12 percent, but never completely removed. True, in 1994 and 1999 Peter Klusen and Lisette Buchholz also used the Swedish original for their intralingual re-rewriting of Klaiber's text, but their corrections were counteracted by new changes. Their re-rewritings were to be shortened versions and numerous deletions led to a deviation rate of 92 and 76 percent respectively. Marijke Reesink in turn used the Swedish original when she re-rewrote (Emmy Weehuizen's originally very faithful interlingual re-rewriting of) a Swedish picture book into Dutch in 1990, but also in this case new changes were carried through at the expense of the corrections, leading to a version which ultimately differed from the Swedish source text to a higher extent than the immediate source text (86 percent vs. 77 percent). Suzanne Braam then, who in 1983 re-rewrote Meyboom's 
primary translation into Dutch, corrected minor constructions and formulations without using the Swedish original. She corrected entirely intralingually, using a correction list, which was based on reader's comments and given to her by the publisher. The corrections concerned only minor constructions and formulations, especially with regard to zoological terminology, and were even in this case counterbalanced by new deletions, so that the re-rewriting could not be said to be more truthful to the original than Meyboom's text.

Still, in favor of the re-rewriting hypothesis it was noticeable that many of the versions in which the immediate source text was corrected, were relatively recent. And recent were also the only five versions that kept the long title of the Swedish original; they were all German versions (with the title Nils Holgerssons wunderbare Reise durch Schweden) and were published in 1991, 1994, 1995, 1995 and 1996.

It is also worth mentioning that one version actually went back to Selma Lagerlöf's own revision of the Swedish original. In 1921 Lagerlöf herself rewrote Nils Holgersson, as the original had proven to be too extensive to use in class, and in 1996 Gisela Perlet re-rewrote this version into German. ${ }^{14}$ The German version, like its Swedish source text, has a deviation rate of 80 percent, but the thought behind the re-rewriting hypothesis is nevertheless present: for the publication of a shortened version the publishing company Reclam chose to show consideration for the original author and to follow Lagerlöf's own selection, instead of making a new shortening. In fact, both Perlet herself and the publisher wanted the re-rewriting to be very faithful to the source text. ${ }^{15}$

Finally, I wish to point out that in some of the intermedial versions, which all date from the eighties and nineties, interference was found with existing Nils Holgersson versions in book form. ${ }^{16}$ Apparently, re-rewriters of the TV-serial tried to make their texts - at least to some minor extent - correspond better with other Nils Holgersson books, which might be seen as evidence of a conscientious treatment of their material in regard to the original text.

\section{A Clash of Norms}

The case study revealed that in recent years there certainly had been a wish to show consideration for the original source text. Conspicuous moral changes, for instance, as in the first German Nils Holgersson by Pauline Klaiber, were no longer found in the subsequent re-rewritings. When all was said and done, however, recent re-rewritings did continue to deviate from the original to quite a large extent. Notably, deletions were numerous. In fact, knowing that the Swedish original consisted of two volumes and almost 700 pages, it is interesting to take a look at the thickness of the different versions as an indication of completeness - or rather incompleteness. If one takes the average number of book pages for the versions per decade, one finds the highest values in the first half of the $20^{\text {th }}$ century (see Figure 1). The highest values for the second half of the century $(353,359)$ correspond to the lowest value for the first half of the century (356) and the highest values do not concern the most recent decades - which would be in line with the re-rewriting hypothesis - but the fifties and sixties. True, the figure shows an upward trend in the last decades, but until further notice this trend does not exceed the highest values of either the first or the second half of the century. 
FIGURE 1

The average number of pages for the corpus, per decade

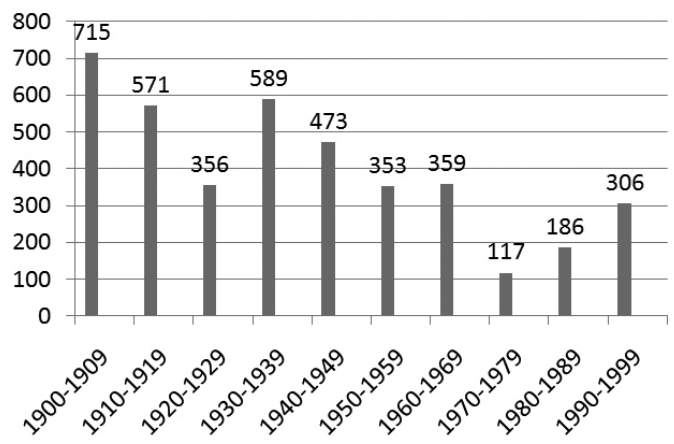

Even in the recent versions, fidelity to the Swedish original was obviously not prioritised. This might be explained in terms of the text type involved. Nils Holgersson is a children's book and belongs to a peripheral literature, for which it is characteristic that several (norm) systems coincide (see also Shavit 1986, Rudvin 1994: 199-211, Rieken-Gerwing 1995). Clearly, norms play a role in every (re)rewriting process, but they are of particular influence when (re)rewriting children's literature, which is on the interface between literature, education, pedagogy as well as economics. The primary source text itself imposes constraints, i.e., norms, on the (re)rewriting process, especially the norm of allegiance to the original, but so does each of the other systems involved and their norms may clash with the norm of allegiance, which was obviously the case for the recent versions of Nils Holgersson. Allegiance to the original did not gain the upper hand, but so did other norms.

First of all, the many geographical facts may have been considered to be irrelevant for the target readers given that Nils Holgersson had changed its main function: instead of an instructive textbook, the book was now primarily thought of as literary entertainment. Literary norms were given priority over educational norms.

Since the sixties, seventies then, pedagogics has wanted children's literature to be 'readable,' which has often led to deletions as well. These deletions are not morally monitored, but have to do with the assumed reading ability of the young readers. When Kari Skjønsberg claims that the (re)rewriting of children's literature in former days tended to be closer to the original text than more recent (re)rewriting (cf. above), she actually explains this in terms of readability. In former days, she argues, making reading material easily accessible to children was not a central issue; it was not considered necessary to make language or contents easier (see Skjønsberg: 41: “[...] man inte var så inriktad på att göra allt stoff lättillgängligt för barn; det ansågs inte nödvändigt att förenkla språk eller innehåll.”).

Plausibly the geographical facts in Nils Holgersson were not only considered to be irrelevant for the target readers, but also too difficult for them.

Further, also economical norms may cause (re)rewriters to limit the size of (rewritten) children's books, especially the norm to restrict expenses. Obviously, the costs are lower if one only wishes to publish a selection of the book. Change may even be caused by time pressure, as time is money. In all probability, time pressure was the reason why the changes in Klaiber's rewriting were reduced but never completely 
removed. A more profound comparison of the existing (re)rewriting with the Swedish original would have been much more (too?) time-consuming, so revision was rather cursory. Economic pressure has even led to so-called anachronisms in the re-rewriting of Klaiber's text. Despite the fact that the publishing company Coron in 1966 edited the Klaiber version that would turn out to be closest to the Swedish original, later versions would still go back to earlier, i.e., less corrected, editions. Clearly, publishing companies did not have the time to conspicuously select a source text.

\section{Conclusion}

One can come up with several factors that make the re-rewriting hypothesis plausible. At the UMST conference in Manchester in 2000, Andrew Chesterman named the following (Chesterman 2000: 15-27):

- Later translators take a critical stance to the earlier translations and seek to improve on them.

- The existence of an earlier translation facilitates the reception of a new one.

- The target language has developed and allows the translator more freedom of movement.

- The target culture translation norms have become less rigid and allow a closer rendering of the source text.

A study of the Swedish children's book Nils Holgersson in German and Dutch (re)rewriting, however, has shown that the hypothesis does not have a general value. Some of the recent versions did show consideration for the original, but there was no overall tendency to go back to the original and produce a source text oriented text. Ultimately, the target culture's norms were decisive, which can be explained in (at least) three ways.

Firstly, as was already anticipated in the introduction of the retranslation hypothesis, the text type plays an important role. Research has shown that (re)rewriters of children's literature tend to prioritise target culture norms (see e.g., Rudvin 1994 and Shavit 1986).

Secondly, Nils Holgersson is a children's classic and classic works are more often subject to change. Indeed, classics are often considered as common property also in the target culture and as a consequence the justification of change may be taken for granted. A study of interlingual, intralingual and intermedial (re)rewritings of Shakespeare, say, will presumably reveal many target oriented versions as well, also recent ones.

Thirdly, it is conspicuous that most articles in Palimpsestes concern texts that are much older than Nils Holgersson or children's books in general. Benhamou discusses for instance Shakespeare's Othello and Berman discusses Plutarch, Vergil and the Bible. Not only text type matters, so it seems, but also time span. Berman does indeed stress the fact that time is only ripe for "big translations" ("grandes traductions") after the publication of numerous studies and adaptations (see Berman 1990: 6: "maintes introductions érudites, scolaires, maintes adaptations"). So maybe a period of 90 years, as in the case study concerned, is too short for the re-rewriting hypothesis to hold. Re-rewritings may become more source text oriented when Nils Holgersson is no longer copyrighted, i.e., from the year 2010, when it will be 70 years since Lagerlöf's death. Hitherto, the existence of copyrighted rewritings (Klaiber's 
rewriting for the German book market and Meyboom's rewriting for the Dutch book market) may actually have been one of the economic factors behind the dominance of indirect and shortened re-rewritings in the corpus; as noted earlier, costs will be lower if one uses an existing translation and only publishes a selection of the book. On the other hand, if Nils Holgersson is no longer copyrighted, it might just as well be that the book is considered as common property even more so and that new target oriented re-rewritings will (continue to) arise. Either way, as for the gradual correction of Klaiber's text in the intralingual re-rewritings from 1909, 1928, 1948 and 1966, the time span is very short. Most striking changes from the first edition from 19071908 were in fact omitted in 1909, when Klaiber's text was re-edited in one volume. Berman does not indicate explicitly how many studies and adaptations are necessary for the big translations to come and Bensimon remains vague when he says that rerewritings arise "after a rather long time period" (Bensimon 1990: ix: "(a)près le laps de temps plus ou moins grand"), but undoubtedly neither Berman nor Bensimon mean a lapse of only one single year. In one year the target culture cannot have covered "the road of experience," as Berman calls it (Berman 1990: 4: "le chemin de l'expérience"), that is necessary to create new (and better) re-rewritings. Still, the basic thought behind the re-rewriting hypothesis can be found even here. Most likely, the first edition from 1907-1908 cleared the path for future re-rewritings. Once the introduction of Nils Holgersson to the German book market had proved successful, changes were no longer necessary.

What thus is the validity of the re-rewriting hypothesis? On the basis of the case study described, one can justifiably say that the global impact of the hypothesis should be toned down as well as the need for a longer maturing process. In general the corpus did not support the hypothesis, as the recent versions did not turn out to be considerably more truthful to the original than earlier versions. Some versions could be seen as corroborative, but they were mostly ambiguous. In my opinion, the hypothesis may certainly be valid to some extent, but only if it is not formulated in absolute terms. In this regard, Goethe's theory of (re)rewriting, a theory which is often referred to by the adherents of the (re)rewriting hypothesis (cf. Berman 1990: 4), links up better with the results of the case study. This theory, according to which (re)rewriting covers three phases, is less absolute, as Goethe does not mention any (necessary) time span. On the contrary, he stresses the fact that the three phases may occur simultaneously, which is exactly the tendency revealed by the case study. The three phases are: (1) a (re)rewriting in plain prose, through which the target culture is acquainted with the original work; (2) a target text oriented (re)rewriting, and (3) (cf. above) a (re)rewriting in which identity with the original is sought (see Goethe 1811/1914: 493ff. and Goethe 1819: 243-246).

Clearly, more research will be necessary to further determine the validity of the re-rewriting hypothesis. In conclusion, I wish to point out the value of further inquiry into the hypothesis for Translation Studies in general. The insights gained regarding the scope of the retranslation hypothesis could as a result be re-linked both to purely theoretical translation studies (translation theory) and to empirical, historical and descriptive translation studies and research. New insights would allow translation scholars to verify whether and to what extent a new view on the concept "(re)translation" is plausible both theoretically and practically. A newer and broader vision that would include various text types and genres and which consequently would not only take 
into account the traditional and most prototypically accepted forms of (re)translation, i.e., direct interlingual (re)rewriting (the fact that direct and interlingual translation is conceived as the most prototypical form of rewriting is discussed in Jakobson 1959: 232-239, Chesterman 1998: 201-230, and Halverson 1998), but also indirect and intralingual and intermedial (re)rewriting. Within peripheral forms of literature, like children's literature, such less prototypical (re)rewriting has proven to be more than the exception. In order to include these and other forms of literature within existing theoretical and empirical translation study frameworks, the scope of terms such as "(re)translation" and "adaptation" and issues such as corpus selection have to be reexamined (cf. van Doorslaer 1995: 245-260). Mooting the re-rewriting hypothesis may contribute to such fundamental questions within the field of Translation Studies. ${ }^{17}$

\section{NOTES}

1. The possibility of not translating the foreign text has also been dealt with by Theo Hermans in answer to Gideon Toury's typology of norms. See Hermans (1999: 76).

2. In this regard, I wish to link up with the usual distinction between written translation and oral interpreting. On this distinction, see e.g., Reiß (1971: 14).

3. Cf. the scopos theory's functionalistic approach (as by Holz-Mänttäri, Nord, Reiß and Vermeer) and the (poly)systemic approach (as by Even-Zohar, De Geest, Shavit, Toury).

4. See Andrew Chesterman's concept of memes. Translations, Chesterman argues, "do not move, they spread, they replicate. In place of the metaphor of movement, therefore, I would suggest one of propagation, diffusion, extension, even evolution: a genetic metaphor" (Chesterman 1997: 8). The metaphor of movement to which Chesterman refers, is the metaphor as expressed in the common terms "source text" and "target text."

5. LAGERLÖF, Selma (1906-1907 - 2 volumes): Nils Holgerssons underbara resa genom Sverige. Stockholm: Albert Bonniers Förlag.

6. German versions discussed:

(1907-1908): Wunderbare Reise des kleinen Nils Holgersson mit den Wildgänsen. Rewritten by Pauline Klaiber. München: Albert Langen (3 volumes).

(1909): Wunderbare Reise des kleinen Nils Holgersson mit den Wildgänsen. Rewritten by Pauline Klaiber. München: Albert Langen (1 volume).

(1919): Niels Holgersens wunderbare Reise mit den Wildgänsen. Rewritten by Mathilde Mann. Leipzig: Hesse \& Becker.

(1928): Wunderbare Reise des kleinen Nils Holgersson mit den Wildgänsen. Rewritten by Pauline KLAIBER. 10th volume of Lagerlöf: Gesammelte Werke in 12 Bänden, München: Albert Langen.

(1942): Wunderbare Reise des kleinen Nils Holgersson mit den Wildgänsen. Rewritten by Pauline Klaiber. München: Albert Langen/Georg Müller.

(1948): Wunderbare Reise des kleinen Nils Holgersson mit den Wildgänsen. Rewritten by Pauline KLAiber. München: Nymphenburger Verlagshandlung.

(1949): Nils Holgerssons wunderbare Reise mit den Wildgänsen. Rewritten by André FoelCKeRSAM. Wien: Bermann-Fischer and Amsterdam, Querido.

(1951): Abenteuer des kleinen Nils Holgersson mit den Wildgänsen. Rewritten by Pauline KLAIBER. Stuttgart: Reclam.

(1961): Nils Holgerssons schönste Abenteuer mit den Wildgänsen. Rewritten by Pauline KLAiber. München: Deutscher Taschenbuch Verlag.

(1966): Lagerlöf, Selma, Wunderbare Reise des kleinen Nils Holgersson mit den Wildgänsen. Rewritten by Pauline KLAiber. Zürich: Coron.

(1980): Nils Holgerssons schönste Abenteuer mit den Wildgänsen. Rewritten by Pauline KLAIBER. 3rd volume of Lagerlöf: Gesammelte Werke in 5 Bänden, München: Nymphenburger Verlagshandlung.

(1985): Nils. Rewritten by Monika Trittibach-Andres. Urdorf: Elk-Verlag.

(1991): Nils Holgerssons wunderbare Reise durch Schweden. Rewritten by Angelika Кuтsch. Hamburg: Dressler. 
(1994): Nils Holgerssons wunderbare Reise durch Schweden. Rewritten by Gisela PerLet. Berlin: Altberliner.

(1994): Nils Holgerssons wunderbare Reise. Rewritten by Pauline KLAIBER and Peter KLusEN. Würzburg: Arena.

Nils Holgerssons wunderbare Reise durch Schweden. Rewritten by Gisela Perlet. Darmstadt: Wissenschaftliche Buchgesellschaft.

(1996): Nils Holgerssons wunderbare Reise durch Schweden. Rewritten by Gisela PerLet. Stuttgart: Reclam.

(1999): Nils Holgerssons schönste Abenteuer mit den Wildgänsen. Rewritten by Pauline KLAIBER Lisette Buchrolz. München: Deutscher Taschenbuch Verlag.

7. Dutch versions discussed:

(1911): Niels Holgersson's wonderbare reis. Rewritten by Margaretha Мечвоом. Amsterdam: H.J.W. Becht (2 volumes).

(1983): Niels Holgersson's wonderbare reis. Rewritten by Margaretha Меувоом and Suzanne BraAm. Amsterdam: H.J.W. Becht.

(1990) De reis van Nils Holgersson. Rewritten by Emmy WeEhuizen and Marijke Reesink. Rotterdam: Lemniscaat.

8. The corpus was selected from a bibliographical survey that was put together in the very first stage of the investigation. This survey covered all German and Dutch 'versions' of Nils Holgersson that were published in the German- and Dutch-speaking area between 1906-1907 and December 2000. The survey showed the publication of books, journals, chapters (some of them published as part of an anthology) as well as publications in braille, on video and LP/cassette and also included the unrevised re-editions of these versions, i.e., editions that were re-edited unaltered by the same publishing company. To determine whether or not a re-edition had been revised, I visited or contacted the libraries concerned and personally checked the editions in question, i.e., I compared them with the first/earlier editions. The editions found unrevised were excluded from the corpus.

9. If translation can be said to be a form of rewriting, retranslation can be said to be a form of "re-rewriting." The double prefix may seem odd, but it can be considered necessary if one explicitly wishes to distinguish between first, primary rewriting and later, subsequent rewriting. Indeed, all re-rewriting is rewriting (just as all retranslating is translating), but not all rewriting is re-rewriting (not all translating is retranslating). In what follows I will use the single and double prefix if it is necessary to make the distinction between primary and subsequent rewriting. In other cases, (re)rewriting will be used as a general label, covering both rewriting and re-rewriting.

10. Berman names the direct and interlingual rewritings into French of Plutarch and Vergil by Amyot and Klossowski respectively; Benhamou's contribution deals with five direct and interlingual rewritings into French of Shakespeare's Othello; Gresset departs from two direct and interlingual rewritings into French of Faulkner's Sanctuary; Topia goes into three rewritings into French of Finnegans Wake, rewritings which are implicitly accepted to be direct and interlingual, and Rodriguez discusses Richard Gray's direct and interlingual rewriting into English of Wagner's Mein Leben.

11. Berman gives the example of Amyot, who was the first to rewrite Plutarch directly from Greek into French. While earlier rewritings into French had been indirectly, from Latin and Italian, as well as partially, one could thus call Amyot's rewriting translation; for the first time certain text parts were now rewritten into French and for the first time this rewriting was direct. On the other hand, however, one could also speak of retranslation as some parts of Plutarch's texts had already been rewritten into French. Even the earlier rewritings of Plutarch, going back to Latin and Italian, are ambivalent in that they from a French point of view and can be called translation (first French version of Plutarch), but from a genealogical point of view can be called retranslation, going back to an intermediate version.

12. The chapters were labelled as shortened, substituted and extended according to fixed criteria. For this criteria the corpus was divided into three groups: (1) the first group rendered the immediate source text very literally; in this group the chapters were labelled as shortened, substituted and/or extended if the change concerned at least 46 words (counted in the Swedish original in order to have an invariable tertium comparationis); (2) the second group was characterised by a frequent deletion of minor words and word combinations; for this group the criterion was 46 words as well, but the words needed to be part of independant sentences and one sentence needed to consist of at least 16 words (again counted in the Swedish original); (3) the third group retold the original story in new words; in this case it was useless to count the original words and a macrostructural 
scheme of the Swedish story was used instead; only if the scheme's macropropositions (for each chapter a macroproposition was formulated, i.e., a summary of the central events) applied on the (re)rewriting, the chapters were labelled as unchanged. If the macropropositions were shortened, substituted and/or extended, the chapters were labelled accordingly. For more details on the method that was used, I refer to Desmidt 2001.

13. As for the Dutch part of the corpus, only Meyboom's rewriting is direct. There are no subsequent direct re-rewritings.

14. Gisela Perlet, who in 1994 had already made a direct and interlingual re-rewriting from the original.

15. Gisela Perlet, telephone-interview by author, Ghent,10 August 2000.

16. This was the case in Schurinks rewriting into Dutch, for instance.

17. From 2001 till 2004 I worked on a project with the working title: «The retranslation hypothesis: myth or reality? as a Postdoctoral Fellow of the Fund for Scientific Research - Flanders (Belgium) (F.W.O. - Vlaanderen) Meta-analysis of existing argumentation." This was an individual project, but it should be stressed that the study of (existing argumentation on) the retranslation hypothesis should be dealt with on a larger scale in order to gain insight into its bearing and its significance for Translation Studies in general.

\section{REFERENCES}

Bensimon, Paul (1990): Présentation. Palimpsestes. 4:iv-xiii.

Berman, Antoine (1990): La retraduction comme espace de la traduction. Palimpsestes. 4:1-7.

Chesterman, Andrew (1997): Memes of Translation: The Spread of Ideas in Translation Theory. Amsterdam: John Benjamins.

Chesterman, Andrew (1998): Causes, Translations, Effects. Target. 10(2):201-230.

Chesterman, Andrew (2000): A causal model for Translation Studies. In: Maeve Olahan, ed. Intercultural Faultlines: Research Models in Translation Studies I: Textual and Cognitive Aspects. Manchester: St. Jerome, 15-27.

De Geest, Dirk (1992): The Notion of 'System': Its Theoretical Importance and its Methodological Implications for a Functionalist Translation Theory. In: Harald KitTeL, ed. Geschichte, System, Literarische Übersetzung; Histories, Systems, Literary Translations. Berlin: Erich Schmidt Verlag, 32-45.

DESMIDT, Isabelle (2001): En underbar färd på språkets vingar: Selma Lagerlöfs Nils Holgersson i tysk och nederländsk översättning/bearbetning. Doctoral dissertation. Ghent: University of Ghent.

Even-Zohar, Itamar (1990): Polysystem Studies. Poetics today. 11(1).

Gambier, Yves (1994): La Retraduction, retour et détour. Meta. 39(3):413-417.

GeETHE, Johann Wolfgang von (1811/1814 [1981]): Aus meinem Leben: Dichtung und Wahrheit. München: Deutscher Taschenbuch Verlag.

Gethe, Johann Wolfgang von (1819 [1962]): West-Östlicher Divan. München: Deutscher Taschenbuch Verlag.

Gresset, Michel (1990): Retraduire, (re)mettre en scène: L'exemple de Sanctuary. Palimpsestes. 4:33-44.

Halverson, Sandra (1997): The Concept of Equivalence in Translation Studies: Much Ado about Something. Target. 9(2):207-233.

Halverson, Sandra (1998): Concepts and Categories in Translation Studies. Ph.D. dissertation. University of Bergen.

Hermans, Theo (1999): Translation in Systems: Descriptive and System-oriented Approaches Explained. Manchester: St. Jerome Publishing.

Jakobson, Roman (1959): On linguistic aspects of translation. In: Rueben Arthur Brower, ed. On Translation. Cambridge: Harvard University Press, 232-239.

Koller, Werner (1995): The Concept of Equivalence and the Object of Translation Studies. Target. 7(2):191-222.

Holz-MäntTäRI, Justa (1984): Translatorisches Handeln: Theorie und Methode. Helsinki: Suomalainen Tiedeakatemia. 
NidA, Eugene A. (1964): Towards a Science of Translating. Leiden: Brill.

NoRD, Christiane (1995): Textanalyse und Übersetzen. Heidelberg: Julius Groos Verlag.

ReIss, Katharina (1971): Möglichkeiten und Grenzen der Übersetzungskritik: Kategorien und Kriterien für eine sachgerechte Beurteilung von Übersetzungen. München: Max Hueber.

Reiss, Katharina, and Vermeer, Hans J. (1984): Grundlegungen einer allgemeinen Translationstheorie. Tübingen: Max Niemeyer Verlag.

Rieken-Gerwing, Ingeborg (1995): Gibt es eine Spezifik kinderliterarischen Übersetzens? Frankfurt am Main: Peter Lang.

Rodriguez, Liliane (1990): Sous le signe de Mercure, la retraduction. Palimpsestes. 4:63-80.

SCHÄfFner, Christina ed. (1999): Translation and Norms. Clevedon: Multilingual Matters.

Schleiermacher, Friedrich (1813 [1963]): Ueber die verschiedenen Methoden des Uebersetzens. In:, Hans Joachim STÖRIG ed. Das Problem des Übersetzens. Darmstadt: Wissenschaftliche Buchgesellschaft, 38-70.

Rudvin, Mette (1994): Translation and 'Myth': Norwegian Children's Literature in English. Perspectives: Studies in Translatology. 2:199-211.

Shavit, Zohar (1986): Poetics of Children's Literature. London: The University of Georgia Press.

SKJønsBerg, Kari (1982): Vem berättar? Om adaptioner i barnlitteratur. Stockholm: Rabén \& Sjögren.

TopiA, André (1990): Finnegans Wake: La traduction parasitee: Étude de trois traductions des dernières pages de Finnegans Wake. Palimpsestes. 4:45-61.

Toury, Gideon (1995): Descriptive Translation Studies and beyond. Amsterdam/Philadelphia: John Benjamins.

Van Doorslaer, Luc (1995): Quantitative and Qualitative Aspects of Corpus Selection in Translation Studies. Target. 7,2:245-260.

\section{INTERVIEW}

Perlet, Gisela (2000): Telephone-interview by author. Ghent, 10 August 2000. 